\title{
INVESTIGATION OF THE INFLUENCE OF LEAD COMPOUNDS WITH PARTICLES OF DIFFERENT DISPERSITY ON HUMAN BLOOD PLASMA PROTEINS AS AN EXPRESS METHOD FOR EVALUATION OF THEIR SAFETY
}

\section{Dmytrukha N. M.', Lahutina O. S.', Gromovoy T. Yu.2 \\ IState Institution «Kundiiev Institute of Occupational Health of the National Academy of Medical Sciences of Ukraine», Kyiv}

\section{${ }^{2}$ Chuiko Institute of Surface Chemistry National Academy of Sciences of Ukraine, Kyiv}

Introduction. The production of lead and its use in various industries cause its entering the human body in the form of an aerosol with particles of different dispersion, including nanosized. Specific physicochemical properties of nanoparticles (NPs), the ability of lead to bioaccumulation and the polytropic toxicity necessitate studying its toxicity and hazard in the nanoscale state.

The purpose of the study - investigate the effect of lead compounds with different particle sizes on human plasma proteins (NPs with the size of $30 \mathrm{~nm}$ and $65 \mathrm{~nm}$, human blood plasma (OA, R+), albumin and human immunoglobulin $\mathrm{G}(\mathrm{IgG})$ (Sigma. The effect of lead compounds on protein structure was determined using an Autoflex II mass spectrometer (Bruker, Germany) and a Mefan spectrophotometer (Ukraine).

Results. The obtained mass spectra of human plasma proteins after incubation with lead nitrate and PbS NPs differed by the availability and intensity of peaks, which is a consequence of different types of interaction of ions and NPs with proteins. Also, the indices of optical density of the studied protein solutions indicate different types of interaction of lead with proteins in the form of ions and NPs. It is shown that the degree of conformation changes of albumin and IgG depends on both the chemical form of lead compounds and the size of nanoparticles, as well as on their concentration in the incubation medium. The largest changes in the protein structure were caused by PbS with NPs of $26-34 \mathrm{~nm}$, and the smallest - by lead nitrate (ionic form). Human IgG was more sensitive to lead compounds than albumin.

Conclusions. The established selective interaction of PbS ions and NPs with blood proteins can lead to changes in the structure of proteins, in their functional activity as well as in properties and behavior of nanoparticles, as it can affect their size, transport, accumulation and elimination. A model «nanoparticles - blood plasma proteins» can be used for express assessment of the biocompatibility of metal NPs and their toxicity.

Key words: lead ions and nanoparticles, human blood plasma, albumin, immunoglobulin G, denaturation, toxicity

\section{Introduction}

Wide use of lead and its compounds in various sectors of the economy, as well as large volumes of production cause excessive entry of the metal in the environment. According to WHO experts, lead is recognized as a global and dangerous pollutant [1].

It is known that when entering the body, lead causes a polytropic toxic effect, disrupts the functioning of the nervous and cardiovascular systems, affects negatively the gastrointestinal tract, kidneys, blood, reproductive and immune systems [2-4].

With the development of nanotechnology there has begun the synthesis and use of lead in the form of nanoparticles (NPs).
Synthesized NPs of lead compounds (PbS, PbSe, $\mathrm{PbTe}$ ) are actively used in the development of new fluorescent materials, lasers, electronic systems, LEDs, solar panels, which in turn can promote human contact with them and create health risks $[4,5]$.

It has been studied that metals in the form of nanoparticles, due to their small size and large surface area, have greater permeability and reactivity, which leads to greater toxicity $[6,7]$. In view of the above, studying the hazards of nanoparticles of heavy metals and their compounds is an important issue. The hazard assessment of nanomaterials includes both traditional toxicological studies and prediction of possible risks and adverse effects on the human body using alternative in vitro test models [8-10]. 
According to the literature data [11], proteins of blood plasma are considered as one of the models for establishing the general toxicity of chemical compounds. This is due to the fact that blood proteins perform a number of important functions in the body: transport (many substances are transported with blood proteins, including metal ions); protective (part of proteins: complement system, interferons, interleukins, etc. provides for nonspecific protection, others - different classes of antibodies perform specific protection against foreign substances and microorganisms); trophic (with a sharp or prolonged restriction of protein intake, proteins are breaking down, forming amino acids, which are used by cells for various plastic processes; also, proteins create osmotic pressure and are involved in maintaining blood $\mathrm{pH}$, as well as protect the body from blood loss (fibrinogen and other factors involved in blood clotting) [12].

Both the amino acid (peptide) sequence and the three-dimensional structure formed during coagulation are extremely important for the functioning of proteins. The three-dimensional structure of proteins under normal natural conditions is called the native state of a protein [13].

It has been studied that the following changes occur during interaction of proteins with heavy metal ions: binding and blocking of active centers of proteins, their denaturation. As a result, a protein molecule loses its native state and necessary properties to functioning in the cell. Denatured proteins acquire other properties, in particular - loss of solubility and aggregation [14].

In our previous studies [15] it is shown that lead ions are able to join the IgG molecule, change its mass, affect the processes of ion formation and disorder functional activity.

As regards nanoparticles (NPs), it is known that they are of approximately the same size as proteins, so an important aspect of their behavior in the human body is their reaction with plasma proteins. The authors [16] have been studied that NPs are able to adsorb proteins from biological fluids and form a protein layer, called a «protein crown». The composition of the protein crown depends on physicochemical properties of NPs, including their size, shape, surface area. A biological reaction of a cell on NPs can depend on protein composition by which it is covered. Therefore, the study of the effect of NPs of lead compounds on blood proteins that perform transport and protective functions is relevant.
The purpose of the study was to investigate the effect of lead compounds with different particle sizes on human plasma proteins (albumin and immunoglobulin $\mathrm{G}$ ) in model experiments in vitro.

\section{Materials and methods of investigation}

Lead compounds were investigated: $\mathrm{Pb}\left(\mathrm{NO}_{3}\right)_{2}$ (ionic form) and $\mathrm{PbS}$ (nanoparticles). Nanoparticles of lead sulfide (NPs of PbS) were synthesized by mixing equimolar amounts of the concentrated $\mathrm{Na}_{2} \mathrm{~S}$ solution $(0,1 \mathrm{~mol} / \mathrm{l})$ and a relatively diluted solution of lead nitrate $\left(\mathrm{Pb}\left(\mathrm{NO}_{3}\right)_{2}\right)\left(3 \cdot 10^{-3} \mathrm{~mol} / \mathrm{l}\right)$, with the addition of a sodium polyphosphate stabilizer $\left(\mathrm{NaPO}_{3}\right) \mathrm{n}\left(5 \cdot 10^{-3} \mathrm{~mol} / \mathrm{l}\right)$ with intensive stirring at $4{ }^{\circ} \mathrm{C}$ and $56{ }^{\circ} \mathrm{C}$.

The size of the PbS nanoparticles was measured using ANALYSETTE 12 DynaSizer laser analyzer (Germany). The particle size in the studied colloidal $\mathrm{PbS}$ solutions was $26-34 \mathrm{~nm}$ and $50-80 \mathrm{~nm}$.

Human plasma (OA, R+) and human albumin and immunoglobulin G ( $\operatorname{IgG}$ ) preparations (Sigma, USA) were used as in vitro models.

A method of MALDI-ToF mass spectrometry was used in the study, which is one of the modern methods for studying macromolecular biological compounds, including proteins, nucleic acids, lipids, oligosaccharides [17, 18].

During the experiment, human blood plasma was diluted with deionized water in a ratio of $1: 100$. In the first series of studies, $0,5 \mathrm{ml}$ of $\mathrm{Pb}\left(\mathrm{NO}_{3}\right)_{2}$ solution was added to $0,5 \mathrm{ml}$ of diluted plasma, and in the second series $-0,5 \mathrm{ml}$ of $\mathrm{PbS}$ solution with NPs sized 26-34 nm was incubated for 2 hours at the temperature of $+22^{\circ} \mathrm{C}$. Then, the solutions were centrifuged at 10,000 rotations/min in $15 \mathrm{~min}$. The solution of blood plasma with deionized water was taken as the control. The studies were performed using a matrix of synaptic acid (Sinapic Acid, Fluka).

The studies were performed in two mass ranges: 6-20 kDa (low molecular weight) and 20-200 kDa (high molecular weight). Protein mass spectra were measured on Autoflex II device (Bruker, Germany). The total spectra of positive ions, which were obtained by accumulating 600 single spectra, were analyzed.

Conformation changes (denaturation) in human plasma proteins after incubation with lead compounds were determined spectrophotometrically by measuring the optical density of the solution as described in the paper [11]. The principle of the 
method is that when adding a reactive chemical compound to the protein, there is a decrease in the transparency of the solution, due to denaturation of the latter.

Protein solutions were prepared with $0,9 \% \mathrm{NaCl}$ with the final protein concentration in the reaction of $1 \mathrm{mg} / \mathrm{ml}$. Lead compounds were added in concentrations $\left(1,10^{-1}, 10^{-2}, 10^{-3} \mathrm{~mol} / \mathrm{l}\right)$ in a ratio of $1: 1$, carefully mixed and incubated for $2 \mathrm{~h}$ at $37^{\circ} \mathrm{C}$. For each protein a series of studies was performed:

$1^{\text {st }}$ test tube $-1 \mathrm{ml}$ of protein $+1 \mathrm{ml}$ of $0,9 \%$ $\mathrm{NaCl}$ (negative control); $2^{\text {nd }}$ test tube $-1 \mathrm{ml}$ of protein $+1 \mathrm{ml}$ of $0,1 \mathrm{M} \mathrm{NaCl}$ with $0,9 \% \mathrm{NaCl}$ (positive control); $3^{\text {rd }}-7^{\text {th }}$ tubes $-1 \mathrm{ml}$ of protein $+1 \mathrm{ml}$ of salt solution or NPs of $\mathrm{PbS}$ in concentrations (1, $\left.10^{-1}, 10^{-2}, 10^{-3} \mathrm{~mol} / \mathrm{l}\right)$. The optical density of the solution of the studied samples was measured in relation to the negative control with the spectrophotometer Mefan (Ukraine) at a wavelength of $405 \mathrm{~nm}$. The percentage of protein denaturation in the test sample was calculated as the ratio: unit of optical density of the tested sample / unit of optical density of the positive control.

Statistical processing of the obtained results was performed using the program of a statistical analysis Exel; the significance of the differences between the control and experimental indicators was determined using a Student's t-test criterion.

\section{Research results and discussion}

Comparative studies on lead effects in the form of nanoparticles ( $\mathrm{NPs}$ of $\mathrm{PbS}$ ) and ions $\left(\mathrm{Pb}\left(\mathrm{NO}_{3}\right)_{2}\right)$ on human plasma proteins by the results of MALDIToF mass spectrometry showed the following. Mass spectra of the low-molecular area of human blood plasma after $2 \mathrm{~h}$ incubation with the solution of $\mathrm{Pb}$ $\left(\mathrm{NO}_{3}\right)_{2}$ did not undergo any significant changes. At the same time, there were some differences in the mass spectra after contact of blood plasma with $\mathrm{NPs}$ of $\mathrm{PbS}$ as compared with the control, which consisted in reducing the relative intensities of all peaks and the absence of peaks at 13770 and 14050 m/z (Fig. 1).

The mass spectra of the high molecular weight area in the tested samples make it possible to state that the values of $66411 \mathrm{~m} / \mathrm{z}$ and $33205 \mathrm{~m} / \mathrm{z}$ belong to the double- and single-charged albumin molecule, the peaks at $150,000 \mathrm{~m} / \mathrm{z}$ correspond to the whole immunoglobulin G ( Ig G) molecule, and $133,000 \mathrm{~m} / \mathrm{z}$ - to albumin dimer (Fig. 2).

The general picture of the blood plasma mass spectrum changed significantly after incubation with NPs of $\mathrm{PbS}$. Thus, the disappearance of the peak corresponding to IgG was observed, as well as the increase of values of $\mathrm{m} / \mathrm{z}$ approximately by $6000 \mathrm{Da}$ belonging to albumin (from $66411 \mathrm{~m} / \mathrm{z}$ to $72150 \mathrm{~m} / \mathrm{z}$ ), as well

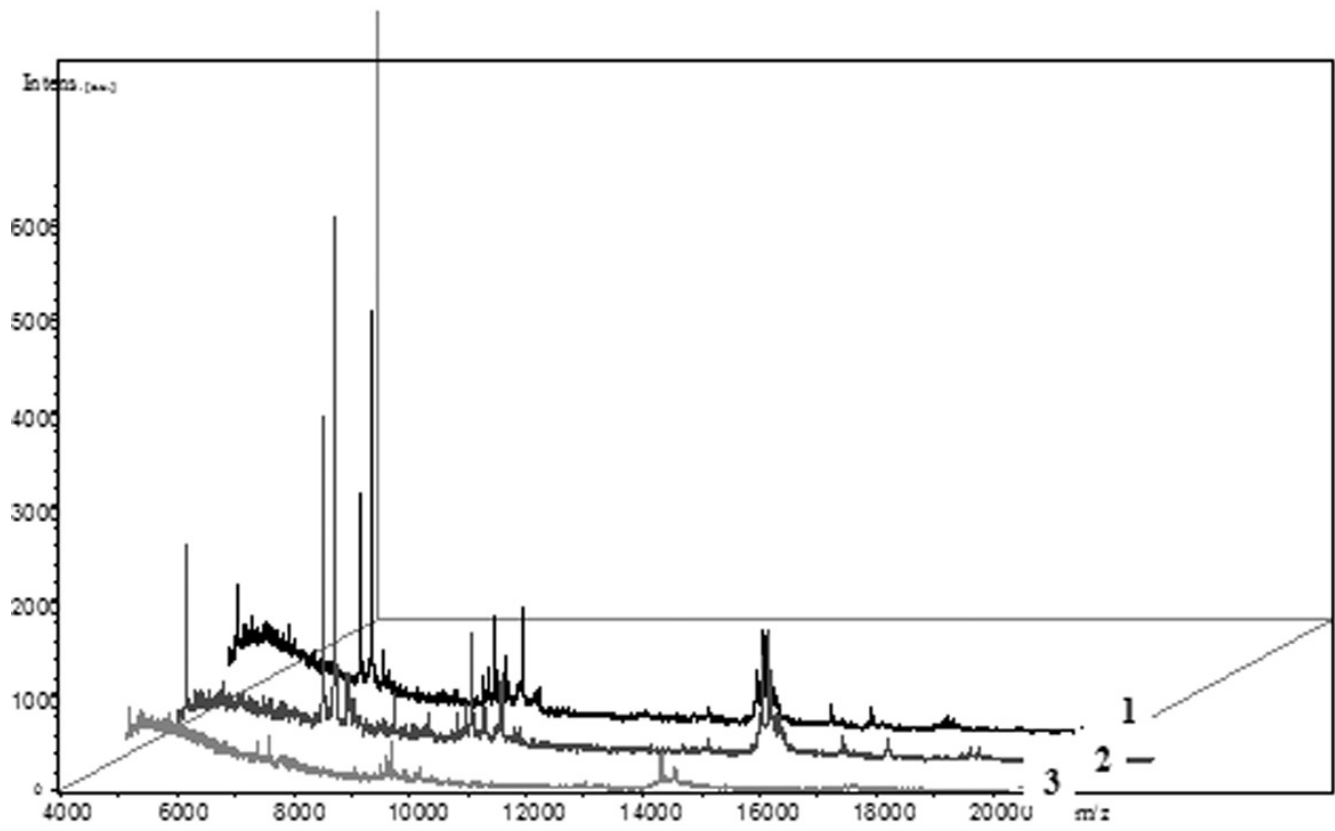

Fig. 1. Mass spectra of the low molecular weight area of human blood plasma: 1 - spectrum of native blood plasma (control); 2 - after incubation with $\mathrm{Pb}\left(\mathrm{NO}_{3}\right)_{2} ; 3$ - after incubation with PbS NPs of 26-34 nm 


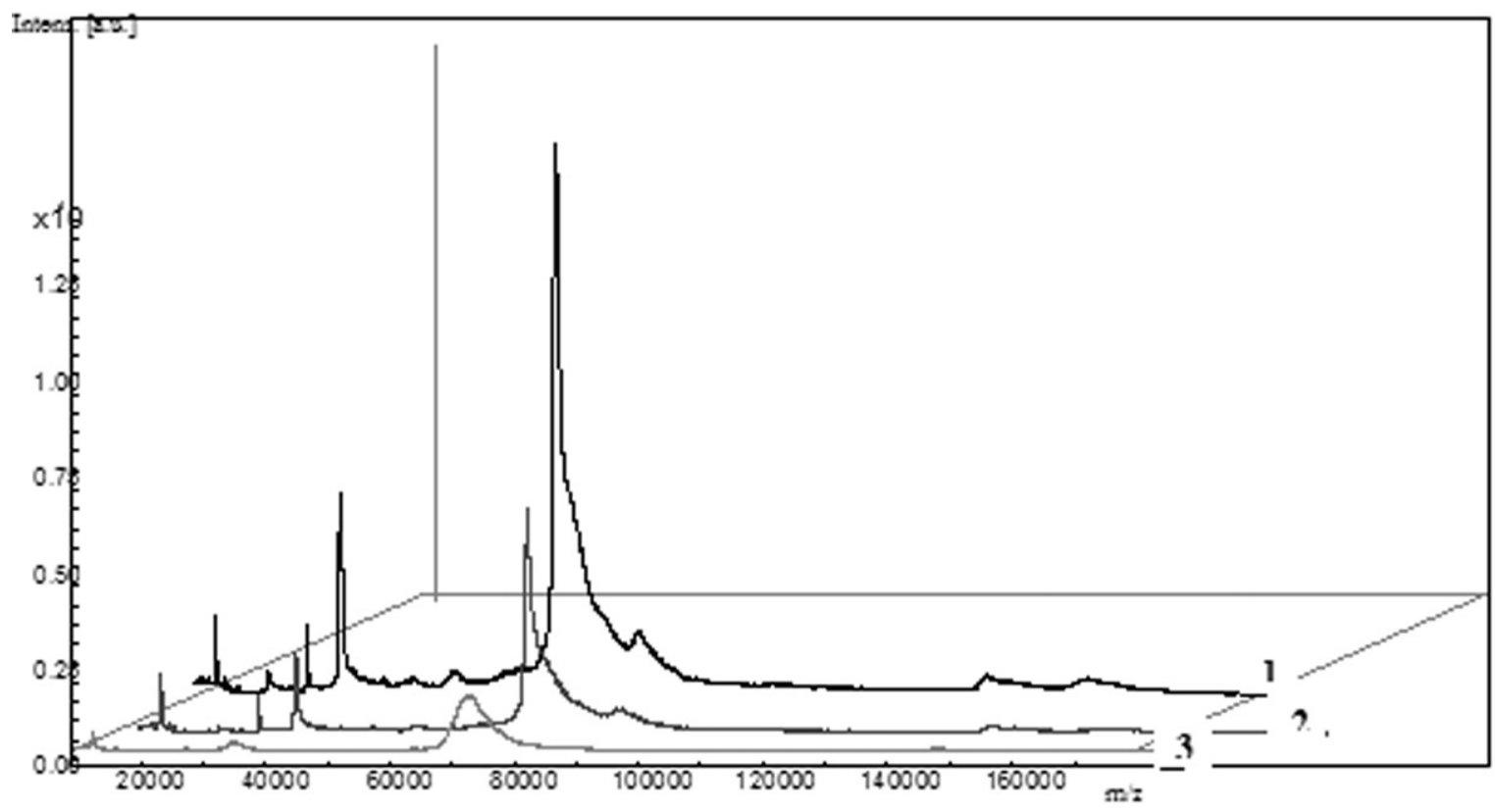

Fig. 2. Mass spectra of the high molecular weight area of human blood plasma: 1- spectrum of native blood plasma (control); 2 - after incubation of plasma with $\mathrm{Pb}\left(\mathrm{NO}_{3}\right)_{2} ; 3$ - after incubation with PbS NPs of 26-34 nm

as its double-charged ion (from $33205 \mathrm{~m} / \mathrm{z}$ up to $36050 \mathrm{~m} / \mathrm{z}$, respectively).

The mass spectra of native human plasma proteins, defined in our studies in low- and high molecular areas, coincided with those obtained by other authors [18]. Therefore, we can assume that the established changes in the mass of albumin and IgG, occurred after incubation of blood plasma with $\left.\mathrm{Pb}\left(\mathrm{NO}_{3}\right)_{2}\right)$ and $\mathrm{NPs}$ of $\mathrm{PbS}$, are the result of different interactions of ions and nanoparticles with these proteins.

Serum albumin is a transport system for various physiologically active substances, including metal ions [19]. The established increase in the mass of the albumin molecule in our experiments may be due to the addition of ions of $\mathrm{Pb}$ and $\mathrm{PbS}$ NPs and can be explained by the fact that the transferred albumin protein plays a leading role in their transportation to organs and tissues.

The disappearance of peaks in the low molecular zone, as well as the peak corresponding to the Ig G molecule after incubation with $\mathrm{NPs}$ of $\mathrm{PbS}$ can be explained by the adsorption of these proteins on the NP surface, which makes it impossible to determine their mass spectrum. This, in turn, can affect their physical characteristics (size, charge) as well as their transport and elimination.

Measurement of the optical density of a solution of human albumin and immunoglobulin G ( Ig G) after incubation with lead compounds in the form of ions and NPs also revealed some differences that depended on the particle size and its concentration (Fig. 3). The highest indicators of the optical density of albumin were determined after its incubation with NPs of $\mathrm{PbS}$ of 26-34 nm at concentrations of $1 \mathrm{~mol} / \mathrm{l}$ and $10^{-1} \mathrm{~mol} / 1$.

Low concentrations of the tested lead compounds $\left(10^{-2}\right.$ and $\left.10^{-3} \mathrm{~mol} / \mathrm{l}\right)$, regardless of particle size, did not significantly affect the structural organization of albumin, while the optical density of the tested samples was close to indices of the negative control (protein + deionized water). The most significant structural disorders in Ig $\mathrm{G}$ were found after incubation with NPs of $\mathrm{PbS}$ at a concentration of $1 \mathrm{~mol} / \mathrm{l}$, as evidenced by the high indices of optical density of the solution. The smallest disorders in the structure of Ig $G$ and changes in the indices of optical density of the tested solutions were determined after incubation with lead compounds at a concentration of $10^{-2}$ and $10^{-3} \mathrm{~mol} / \mathrm{l}$ (Fig. 3).

Based on the measured indicators of the optical density of protein solutions in accordance with the method [11], we calculated the percentage of denaturation of albumin and Ig G (Table).

It is found that the highest percentage of denaturation of Ig $\mathrm{G}$ during incubation with lead compounds 
Optical density of human albumin solution

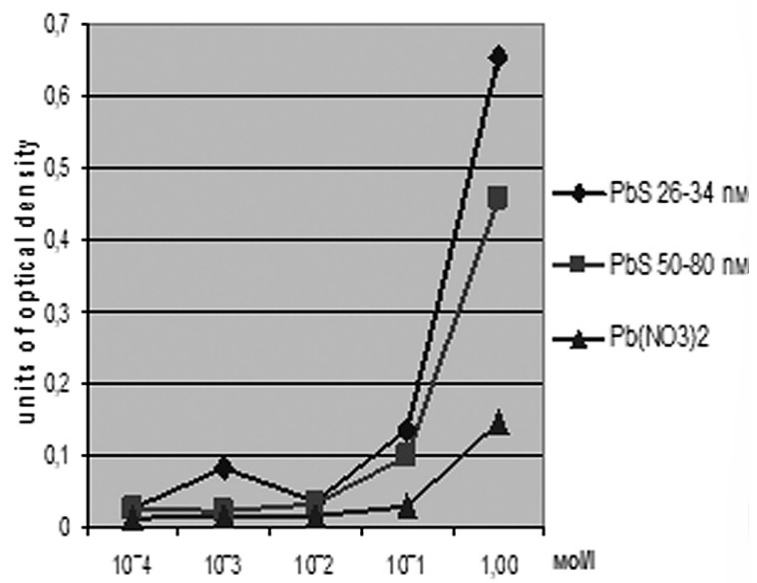

Optical density of human $\lg G$ solution

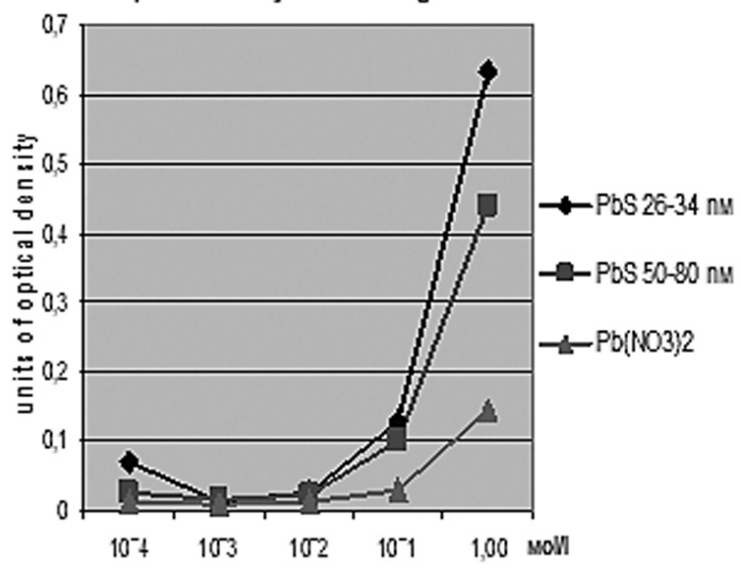

Fig. 3. Changes in the optical density of human albumin and immunoglobulin G solutions after incubation with lead nitrate and lead sulfide nanoparticles of different sizes in the range of metal concentrations of $1-10^{-3} \mathrm{~mol} / \mathrm{l}$ (wavelength $405 \mathrm{~nm}$ )

at a concentration of $1 \mathrm{~mol} / 1$ was caused by NPs of $\mathrm{PbS}$ of $26-34 \mathrm{~nm}(66,74 \%)$, compared with NPs of $\mathrm{PbS}$ of $50-80 \mathrm{~nm}(46,11 \%)$ and lead nitrate $(20,0 \%)$. Denaturation of albumin under the influence of the same concentration of NPs of $\mathrm{PbS}$ of 26-34 nm was $29,26 \%$, NPs of PbS of $50-80 \mathrm{~nm}-$ $12,11 \%$, and $\mathrm{Pb}\left(\mathrm{NO}_{3}\right)_{2}-17,37 \%$.

A tenfold decrease in the concentration of NPs and lead ions $\left(10^{-1} \mathrm{~mol} / \mathrm{l}\right)$ in the incubation solution caused correspondingly smaller changes in the protein structure. In particular, NPs of PbS of 26-34 nm and of 50-80 nm caused denaturation of albumin by $6,42 \%$ and $5,47 \%$, and $\mathrm{Pb}\left(\mathrm{NO}_{3}\right)_{2}-2,32 \%$, and Ig $G-13,47 \%, 10,53 \%$ and $6,32 \%$, compared to the positive control.

Minor changes in the structure of proteins occurred under the influence of NPs of PbS at a concentration of 10-2 mol/l. Denaturation of albumin under the influence of NPs of PbS of 26-34 nm made 2,21\%, NPs of $\mathrm{PbS}$ of $50-80 \mathrm{~nm}-0,95 \%$, and $\mathrm{Ig} \mathrm{G}$ $2,74 \%$ and $1,16 \%$. The smallest changes in the structure of proteins were observed under the influence of lead nitrate at a concentration of $10^{-3} \mathrm{~mol} / \mathrm{l}$ (denaturation of albumin made $0,11 \%$, and Ig G $1,05 \%$ ) (Table).

The obtained data suggest that human IgG after incubation with the studied lead compounds underwent more pronounced conformation changes, compared to albumin. The determined indicators of the optical density of human albumin and Ig G solutions and $\%$ of their denaturation after incubation with $\mathrm{Pb}\left(\mathrm{NO}_{3}\right)_{2}$ and $\mathrm{NPs}$ of $\mathrm{PbS}$ can be evidence of different nature of the interaction of lead ions and nanoparticles with these proteins.

Tahle

Indices of denaturation of human plasma proteins under the influence of lead compounds with different particle size (in \% relative to the positive control)

\begin{tabular}{|c|c|c|c|c|}
\hline \multirow{2}{*}{ Proteins/lead compounds } & \multicolumn{4}{|c|}{ Lead concentration, mol/l } \\
\hline & 1 & $10^{-1}$ & $10^{-2}$ & $10^{-3}$ \\
\hline \multicolumn{5}{|c|}{ Human albumin } \\
\hline NPs of $\mathrm{PbS}$ of $26-34 \mathrm{~nm}$ & 29,26 & 6,42 & 2,21 & 0,11 \\
\hline NPs of PbS of $50-80 \mathrm{~nm}$ & 12,11 & 5,47 & 0,95 & 1,26 \\
\hline $\mathrm{Pb}\left(\mathrm{NO}_{3}\right)_{2}$ & 17,37 & 2,32 & 0,42 & 0,21 \\
\hline \multicolumn{5}{|c|}{ Human immunoglobulin $G$} \\
\hline NPs of PbS of 26-34 nm & 66,74 & 13,47 & 2,74 & 1,47 \\
\hline NPs of PbS of $50-80 \mathrm{~nm}$ & 46,11 & 10,53 & 2,42 & 1,05 \\
\hline $\mathrm{Pb}\left(\mathrm{NO}_{3}\right)_{2}$ & 20,00 & 6,32 & 1,16 & 1,26 \\
\hline
\end{tabular}


In studies [20] it was found that albumin when added to the solution of NPs of PbS covered the surface of nanoparticles, affected their size, as evidenced by the broadening of the bands of diffraction reflection. Other authors [21] considered the possibility of using colloidal gold nanoparticles conjugated with immunoglobulins to develop immunochemical methods for identifying pathogens of infectious diseases.

The results of our research allow us to draw the following conclusions.

\section{Conclusions}

1. It was found that changes in the mass spectra of human plasma proteins and indices of the optical density of their solutions after incubation with lead compounds with particles of different dispersion depended on the chemical nature of the compound, particle size and their concentration in the incubation medium.

2. The difference in mass spectra and conformation disorders in human plasma proteins after incubation with NPs of $\mathrm{PbS}$ and $\mathrm{Pb}\left(\mathrm{NO}_{3}\right)_{2}$ is a conse-

\section{References}

1. Hygienic criteria of the environment: Lead, (1980), V. 3, WHO, Geneva.

2. Privalova L. I., Katsnelson B. A., Gurvich V. B. et al, (2004), "Lead in the environment as a risk factor for the population health", Zhurnal Ros.Khim obshchestva im. D.I. Mendeleeva, XLVIII, 87-93.

3. Korbakova A. I., Sorokina N. S., Molodkina N. N. et al. (2001), "Lead and its effect on the body (literature review)", Gigiyena truda, 5, 29-34.

4. Narysy $z$ toksykologii vazhkykh metaliv. Vypusk I Svynets [Essays on toxicology of heavy metals. Issue I Lead], (ed. I. M. Trachtenberg), Avicenna, Kyiv, Ukraine.

5. Trakhtenberg I. M., Dmytrukha N. M., Lugovskiy S. P. et al. (2015), "Lead is a dangerous pollutant. The problem is both old and new", Suchasni problemy toksykolohiyi, kharchovoyi ta khimichnoyi bezpeky, 71 (3), 14-24.

6. Trakhtenberg I. M., Dmytrukha N. M. (2013), "Nanoparticles of metals, methods of definition, spheres of use, physico-chemical and toxic properties", Ukrainian Journal of Occupational Health, 37 (4), 62-74. https:// doi.org/10.33573/ujoh2013.04.062.

7. Hardman R. (2006), "A toxicologic review of quantum dots: toxicity depends on physicochemical and environmental factors", Environ. Health Perspect., 114 (2), 165-172. https://doi.org/10.1289/ehp.8284. quence of the different nature of the interaction of ions and nanoparticles with proteins.

3. The largest conformation changes in proteins according to MALDI-ToF mass spectrometry and indices of the optical density of the control and tested samples were caused by PbS NPs with the size of $26-34 \mathrm{~nm}$, and the smallest - by lead ions $\left(\mathrm{Pb}\left(\mathrm{NO}_{3}\right)_{2}\right)$.

4. It is established that human immunoglobulin $\mathrm{G}$ is more sensitive to the effects of lead NPs than albumin. This may be due to different protein functions. Albumin as a transport protein performs its function by binding metal ions and NPs in the blood, their transfer to organs and tissues, whereas Ig $G$ are antibodies that perform a protective function and eliminate ions and NPs from the body.

5. The results of the study indicate that the experimental model «nanoparticles - blood plasma proteins» can be used for express assessment of NPs biocompatibility and further improvement of methodical approaches to assess the hazards of heavy metal compounds and their nanoparticles.

8. Eskov A. P., Kayumov R. I., Sokolov A. E. (2003), "Toxicological tests. Alternative methods", Toksikologicheskiy vestnik, 5, 25-28.

9. Prodanchuk N. G., Balan G. M. (2009), "Nanotoxicology: State and perspectives of investigations», Modern problems of toxicology, 3-4, 4-18.

10. Kartel M. T., Tereshchenko V. P. (2008), "The concept of methodology for identification and toxicological studies of nanomaterials and risk assessment for the human body and the environment in their production and use». Collection of scientific works, Khimiia, fizika i tekhnologhia hjverkhnosti. Naukova dumka, Kyiv, 14, 565-583.

11. Lukyanov A. S., Semina T. K., Korolev A. M. (2006), "Prediction of parameters of acute toxicity of chemical compounds by conformation changes in proteins in vitro", Meditsina truda i promyshlennaya ekologiya, 5, 33-40.

12. Biokhimiya. Pidruchnyk dlya vuziv [Biochemistry. Textbook for high education]. (1995), (eds. Kucherenko M.E. e.a.), Lybid, Kyiv, Ukraine.

13. Chekunova M. P., Frolova A. D. (1986), «Modern concepts on the biological action of metals", Gigiyena $i$ sanitaria, 12, 18-21.

14. Trachtenberg I. M., Pokrovsky V. O., Dmytrukha N. M. et al. (2009), "Investigations on the effect of heavy metal compounds on human serum immunoglobulin by MALDI-TOF mass spectrometry", Modern problems of toxicology, 1, 37-41. 
15. Kharazian B., Hadipour N. L., Ejtehadi M. R. (2016), "Understanding the nanoparticle-protein corona complexes using computational and experimental methods", J Biochem Cell Biol., 75, 162-174. https:// doi.org/10.1016/j.biocel.2016.02.008.

16. Lundqvist M., Augustsson C., Lilja M. et al. (2017), "The nanoparticle protein corona formed in human blood or human blood fractions", PLoS ONE, 12 (4), e0175871. https://doi.org/10.1371/journal.pone.0175871.

17. Glen L. Hortin. (2006), "The MALDI TOF Mass Spectrometric View of the Plasma Proteome and Peptidome», Clinical Chemistry, 57 (22), 1-11.

18. Porublyova L. V., Rebriev A. V., Gromoviy T. Yu. et al. (2009), "MALDI - TOF mass spectrometry in the study of macromolecular biological compounds", Ukrainian Biochemical Journal, 81 (3), 46-57.
19. High Mass Linear Analysis of Intact Proteins on the 4800 MALDI TOF/TOF Analyzer, Technical Note.URL: http: / / www.appliedbiosystems.com.

20. Zhang, J., Ma, X., Guo, Y. et al. (2010), "Sizecontrollable preparation of bovine serum albuminconjugated $\mathrm{PbS}$ nanoparticles", Materials Chemistry and Physics, 119 (1), 112-117. https://doi.org/10.1016/j. matchemphys.2009.08.027.

21. Spitsin A. N., Utkin D. V., Kireyev M. N. et al. (2018), "Optical Detection of Immune Complexes Using Colloidal Gold Nanoparticles", Optika $i$ spektroskopiya, 125 (5), 716-720. https://doi. org/10.1134/S0030400X18110280.

\title{
Амитруха Н. М.', ^агутіна О. С.', Громовий Т. Ю.²
}

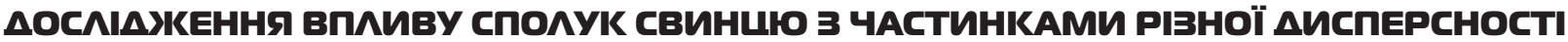 НА БIАКИ ПААВМИ КРОВІ АЮАИНИ ЯІК ЕКСПРЕС-МЕТОА ОЩНКИ ЇХНЬОÏ HEEЕ尹ПEЧHOCTI}

\author{
\Аержавна установа «Інститут медицини праші імені Ю. І. Кундієва Нашіональної академії \\ медичних наук України», м. Київ
}

\section{нститут хімії поверхні ім. О. О. Чуйка Нашіональної академії наук України, м. Київ}

Bcmyn. Виробництво свинцю та його застосування в різних галузях промисловості зумовлює його надходження в організм людини у вигляді аерозолю з частинками різної дисперсності, у тому числі нанорозмірними. Особливі фізико-хімічні властивості наночастинок (НЧ), здатність свинцю до біокумуляції, політропність токсичної дії обумовлюють необхідність проведення досліджень його токсичності та небезпечності в нанорозмірному стані.

Мета дослідження - вивчення впливу сполук свинцю з різними розмірами частинок на білки плазми крові людини (альбумін та імуноглобулін G) у модельних дослідах in vitro.

Матеріали та методи дослідження. Об'єктом дослідження були різні сполуки свинцю: нітрат свинцю (іонна форма) i HЧ $\mathrm{PbS}$ розміром 26-34 нм і 50-80 нм, плазма крові людини (OA, R+), препарати альбуміну та імуноглобуліну $\mathrm{G}$ ( $\mathrm{IgG}$ ) людини. Вплив сполук свинцю на структуру білків визначали за допомогою MALDI-ToF мас-спектрометра (Німеччина) і спектрофотометра Мефан (Україна).

Результати. Отримані мас-спектри білків плазми крові людини після інкубації з нітратом свинцю та HЧ РbS відрізнялись за наявністю та інтенсивністю піків, що є наслідком різного типу взаємодії іонів і НЧ із білками. Показники оптичної густини розчинів досліджуваних білків також вказують на різні типи взаємодії свинцю з білками у формі іонів і НЧ. Показано, що ступінь конформаційних змін альбуміну та IgG залежав як від хімічної форми сполук свинцю, так і від розміру наночастинок, а також від їхньої концентрації в інкубаційному середовищі. Найбільші зміни у структурі білків викликали $\mathrm{HЧ} \mathrm{PbS} \mathrm{26-34} \mathrm{нм,} \mathrm{а} \mathrm{найменші} \mathrm{-} \mathrm{нітрат} \mathrm{свинцю} \mathrm{(іонна} \mathrm{форма).} \mathrm{IgG}$ людини виявився більш чутливим до впливу сполук свинцю ніж альбумін.

Висновки. Встановлена селективна взаємодія іонів і $\mathrm{HЧ} \mathrm{PbS} \mathrm{із} \mathrm{білками} \mathrm{крові} \mathrm{може} \mathrm{призвести} \mathrm{до} \mathrm{зміни} \mathrm{як} \mathrm{структури}$ білків, їхньої функціональної активності, так і властивостей та поведінки наночастинок, оскільки може впливати на їхній розмір, транспорт, накопичення та елімінацію. Модель «наночастинки - білки плазми крові» може бути використана для експрес-оцінки біосумісності НЧ металів та їхньої токсичності.

Ключові слова: іони та наночастинки свинцю, плазма крові людини, альбумін, імуноглобулін G, денатурація, токсичність 
ISSN 2223-6775, Ukrainian Journal of Occupational Health, 2020, 16 (3), 202-209

\section{Амитруха Н. Н.', Магутина О. С.', Громовой Т. ю.² ИССАЕАОВАНИЕ ВАИЯНИЯ СОЕАИНЕНИЙ СВИНИА РАЗАИЧНОЙ АИСПЕРСНОСТИ НА БЕАКИ ПААВМЫ КРОВИ ЧЕАОВЕКА КАК ЭКСПРЕСС-МЕТОА ОUЕНКИ ИХ БËOกАСНОСТИ}

'Государственное учрежАение «Институт медишины труда имени Ю. И. КунАиева Национальной акаАемии медицинских наук Украины», г. Киев

\section{Институт химии поверхности им. А. А.Чуйко Национальной академии наук Украины, г. Киев}

Вступление. Производство свинца и его применение в различных отраслях промышленности обуславливает его поступление в организм человека в виде аэрозоля с частицами различной дисперсности, в том числе наноразмерными. Особые физико-химические свойства наночастиц (НЧ), способность свинца к биокумуляции и политропность токсического действия обусловливают необходимость проведения исследований его токсичности в наноразмерном состоянии.

Цель исследования - изучение влияния соединений свинца с различными размерами частиц на белки плазмы крови человека (альбумин и иммуноглобулин $\mathrm{G}$ ) в модельных опытах in vitro.

Материалы и методы исследования. Объектом исследования были различные соединения свинца: нитрат свинца (ионная форма) и сульфид свинца (НЧ размером 30 нм и 65 нм), плазма крови человека (OA R+), препараты альбумина и иммуноглобулина $\mathrm{G}$ ( $\mathrm{IgG}$ ) человека (Sigma). Влияние соединений свинца на структуру белков исследовали с помощью MALDI-ToF масс-спектрометра (Германия) и спектрофотометра Мефан (Украина).

Результаты. Полученные масс-спектры белков плазмы крови человека после инкубации с нитратом свинца и НЧ $\mathrm{PbS}$ отличались по наличию и интенсивности пиков масс, что является следствием различного типа взаимодействия ионов и НЧ с белками. Показатели оптической плотности растворов исследуемых белков также указывают на различные типы взаимодействия свинца с белками в форме ионов и НЧ. Показано, что степень конформационных изменений альбумина и $\mathrm{IgG}$ зависела как от формы соединений свинца, так и от размера частиц, а также от их концентрации в инкубационной среде. Наибольшие изменения в структуре белков вызвали НЧ $\mathrm{PbS} 26-34$ нм, а наименьшие - нитрат свинца (ионная форма). $\operatorname{IgG}$ человека оказался более чувствительным к воздействию соединений свинца, чем альбумин.

Bыводы. Установлено селективное взаимодействие ионов и $\mathrm{HЧ} \mathrm{PbS}$ с белками плазмы крови, которое может привести к изменению как структуры белков, их функциональной активности, так и свойств и поведения наночастиц, что может влиять на их размер, транспорт, накопление и элиминацию. Модель «наночастицы - белки плазмы крови» может быть использована для экспресс-оценки биосовместимости НЧ металлов и их токсичности.

Ключевые слова: ионы и наночастицы свинца, плазма крови человека, альбумин, иммуноглобулин G, денатурация, токсичность

ORCID ID співавторів та їхній внесок у підготовку та написання статті:

Дмитруха Н. М. (ORCID ID 0000-0001-9161-3889) - аналіз результатів дослідження, формулювання висновків, підготовка матеріалу до друку;

Лагутіна О. С. (ORCID ID 0000-0003-0723-1293) - виконання експериментальних досліджень, проведення статистичної обробки даних;

Громовий Т. Ю. (ORCID ID 0000-0003-2157-5033) - виконання вимірювань та аналіз мас-спектрів білків на приладі Autoflex II - (Bruker), підготовка матеріалу до друку.

Інформація щодо джерел фінансування дослідження: дослідження виконано за темами: «Порівняльна токсичність мікро- і наночастинок свинцю в експериментах in vitro та in vivo (до проблеми удосконалення принципів і методів токсиколого-гігієнічних досліджень важких металів), № ДР 0110U000299; «Наукове обгрунтування принципів, методів і показників експериментальної оцінки токсичності наночастинок і наноматеріалів (на прикладі важких металів), № держреєстрації 0113 U001447.

Надійшла: 1 липня 2020 р.

Прийнята до друку: 29 липня 2020 р.

Контактна особа: Дмитруха Наталія Миколаївна, ДУ «Інститут медицини праці імені Ю. І. Кундієва НАМНУ», буд.75, вул. Саксаганського, м. Київ, 01033. Тел.: + 380442895185. 